\title{
THE RELATIONSHIP BETWEEN LEGAL UNDERSTANDING, ATTITUDES AND DENTIST'S BEHAVIOR ON COMPLETING MEDICAL RECORDS IN SEMARANG
}

\author{
Tahta Danifatis Sunnah *, Erdianto Setya Wardhana **, Hayyu Bondan Aurora *** \\ ^ Departemen Ilmu Kesehatan Gigi Masyarakat Fakultas Kedokteran Gigi Universitas Islam Sultan Agung \\ **, Departemen IImu Kesehatan Gigi Masyarakat Fakultas Kedokteran Gigi Universitas Islam Sultan Agung \\ ***Program Pendidikan Dokter Gigi Fakultas Kedokteran Gigi Universitas Islam Sultan Agung \\ Correspondence : $\underline{\text { Tahtadani@gmail.com }}$
}

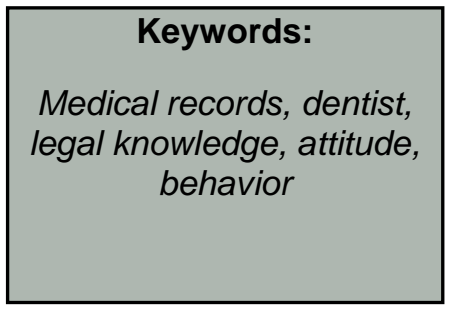

\section{PENDAHULUAN}

Rekam medis biasanya digunakan untuk memudahkan tenaga kesehatan untuk membantu dalam pemberian tindakan pengobatan dan sebagai media komunikasi antar tenaga medis atau kesehatan lainnya. Rekam medis adalah keterangan baik yang tertulis/terekam tentang identitas pasien, anamnesis, penentuan fisik, laboratorium, diagnosa segala pelayanan serta tindakan yang diberikan kepada pasien dan pengobatan baik di rawat jalan, rawat inap, dan gawat darurat. ${ }^{1}$ Berdasarkan hasil wawancara Gita
Kencana 2019 dalam penelitiannya yang berjudul Analisa Kepatuhan Pengisian Berkas Rekam Medis di Instalasi Rawat Inap Rumah Sakit X, Ketidaklengkapan pengisian rekam medis akan berdampak pada intern dan ekstern rumah sakit. Kelengkapan rekam medis bertujuan untuk tercapainya tertib administrasi dan menjadi salah satu data yang berkaitan dengan penyusunan berbagai perencanaan rumah sakit serta pengambilan keputusan oleh pimpinan rumah sakit. 2 
Adapun faktor yang mempengaruhi kelengkapan rekam medis antara lain: Factor man atau sumber daya manusia yaitu kurangnya kesadaran dokter untuk mengisi rekam medis, Factor machine atau kebijakan yaitu tidak adanya kebijakan, panduan atau SOP pengisian rekam medis Factor method atau prosedural yaitu sistem pencatatan oleh petugas belum maksimal, kurangnya evaluasi terhadap ketidak lengkapan dokumen rekam medis. Factor material atau alat yaitu tidak adanya ceklis penilaian kelangkapan rekam medis. Factor money atau dana adalah factor yang menghambat penunjangan rekam medis karena dana yang dimiliki terbatas. . $^{3,4,5}$

Ketidak lengkapan pengisian rekam medis akan berdampak pada intern dan ekstern rumah sakit. Dampak intern salah satunya dapat menghambat penyimpanan rekam medis karena berkas yang belum lengkap akan dikembalikan lagi ke instalasi rawat inap. Sedangkan dampak ekstern

\section{METODE PENELITIAN}

Penelitian ini mendapat persetujuan dari Komite Etik Fakultas Kedokteran Gigi Universitas Islam Sultan Agung Semarang dengan nomor sertifikat Ethical Clearance 223 B.1-KEPK/SAFKG/IX/2020. Menggunakan jenis penelitian observasional analitik dengan desain penelitian cross-sectional study. Jumlah sample sebanyak 44 responden menggunakan simple random sampling dan diuji dengan rumus Slovin. Terdapat dua kriteria sampel yaitu kriteria inklusi yang meliputi dokter gigi lulusan tahun 2017-2019, rekam medis pasien baru, Subjek penelitian berada di kota yaitu terhambatnya proses klaim asuransi yang diajukan dan terhambatnya proses tertib administrasi. ${ }^{2}$ Rekam medis juga digunakan sebagai bukti tertulis atas segala tindakan pelayanan dan sebagai perlindungan hukum bagi pasien, rumah sakit maupun dokter serta tenaga kesehatan lainnya. Sanksi pidana berkaitan dengan rekam medis yang diatur dalam UUPK pasal 79 butir b yang menyatakan bahwa setiap dokter dan dokter gigi yang dengan sengaja tidak membuat rekam medis sebagaimana dimaksud dalam Pasal 46 ayat (1) maka akan dipidana dengan pidana kurungan paling lama 1 (satu) tahun atau denda paling banyak Rp. 50.000.000,00 (lima puluh juta rupiah) .6 .7

Berdasarkan latar belakang tersebut penulis ingin mengetahui bagaimana hubungan antara tingkat pengetahuan hukum dan kelengkapan pengisian rekam medis oleh Dokter Gigi di Kota Semarang.

semarang. Kritesia eksklusi meliputi rekam medis rusak, dan rekam medis tidak dapat dibaca.Instrument penelitian yang digunakan berupa checklist dan kuesioner. Data dari checklist dan kuisioner dikumpulkan untuk persiapan pengolahan dan data dikumpulkan kemudian dilakukan analisis data kemudian dinilai dari presentase kelengkapan rekam medis pada setiap responden dan setiap penilaian yang dilakukan oleh peneliti akan di uji analisis non-parametrik.

sebanyak 45 (dokter gigi). Sebelum dilakukan penelitian, peneliti melakukan uji validitas dan reliabilitas terhadap instrument yang akan 
digunakan. Untuk menguji hipotesis yang digunakan uji regresi logistik yang dilakukan terhadap semua variabel yaitu pemahaman hukum, sikap dan perilaku dokter gigi terhadap kelengkapan pengisian rekam medis.
Hasil penelitan menggunakan kuesioner terhadap 45 dokter gigi yang bekerja di klinik pribadi atau klinik swasta yang berada di Kota Semarang, didapatkan hasil yang dirangkum dengan diagram dan tabel dibawah ini.

Gambar.1 Hasil Penulisan Rekam Medis Dokter Gigi di Kota Semarang

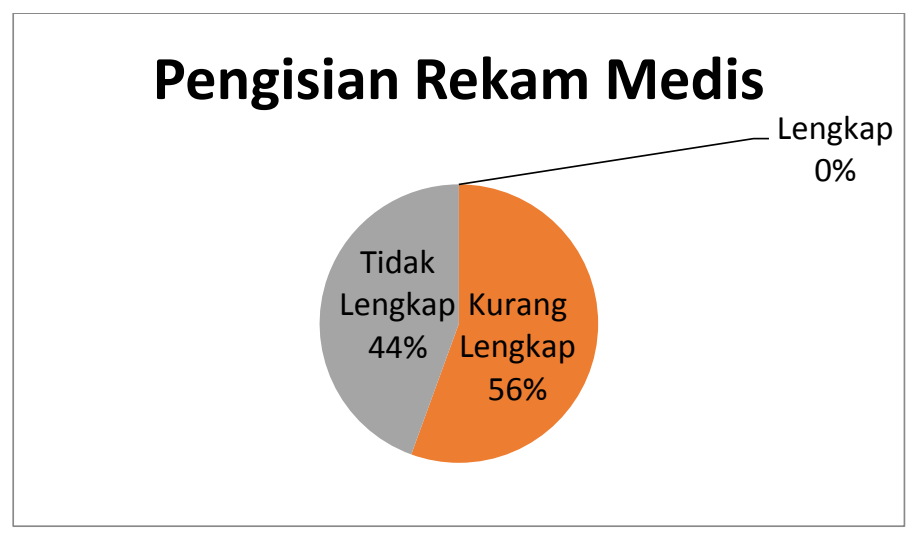

Berdasarkan gambar 1 hasil penulisan rekam medis Dokter Gigi di kota Semarang didapatkan penulisan yang tidak lengkap sebesar $44 \%$ atau sebanyak 20 responden dokter gigi. Penulisan rekam medis yang termasuk kategori kurang lengkap sebesar $56 \%$ atau sebanyak 25 responden dokter gigi. Penelitian yang didapatkan tidak menemukan penulisan rekam medis dokter gigi yang termasuk ketegori lengkap

Tabel.1 Penilaian Kelengkapan Rekam Medis

\begin{tabular}{|c|c|c|c|}
\hline \multirow[t]{2}{*}{ No. } & \multicolumn{2}{|r|}{ Isi Rekam Medis } & \multirow{3}{*}{$\begin{array}{c}\begin{array}{c}\text { Total } \\
\text { Responden }\end{array} \\
45\end{array}$} \\
\hline & & & \\
\hline & Identitas Pasien & 1. Identitas diri pasien & \\
\hline & & 2. Penyakit yang perlu diperhatikan & 32 \\
\hline 2. & Odontogram & 1. Sesuai dengan standar KEMENKES & 18 \\
\hline \multirow[t]{6}{*}{3.} & Tabel Perawatan & 1. Tanggal & 45 \\
\hline & & 2. Gigi yang dirawat & 45 \\
\hline & & 3. Keluhan/diagnose & 44 \\
\hline & & 4. Kode ICD 10 & 2 \\
\hline & & 5. Perawatan & 43 \\
\hline & & 6. $\quad$ Paraf dokter gigi & 41 \\
\hline \multirow[t]{2}{*}{4.} & Lampiran & 1. Inform consent & 15 \\
\hline & pelengkap & 2. Foto Rontgen & 0 \\
\hline
\end{tabular}


Berdasarkan tabel 1 didapatkan hasil pada nomor 1 poin identitas pasien sebanyak 100\% dokter gigi atau sebanyak 45 dokter gigi mengisi identitas diri pasien tetapi dalam poin penyakit yang perlu diperhatikan didapatkan $71 \%$ atau sebanyak 32 responden dokter gigi yang mengisi. Pada nomor 2 mengenai pengisian odontogram yang sesuai dengan standart KEMENKES didapatkan hasil $42 \%$ atau sebanyak 18 dokter gigi yang mengisi odontogram. Pada nomor 3 mengenai tabel perawatan poin tanggal dan gigi yang dirawat didapatkan $100 \%$ atau sebanyak 45 dokter gigi mengisi form tersebut dengan lengkap, sedangkan diagnosa didapatkan $98 \%$ atau sebanyak 44 responden dokter gigi yang mengisi. Pada poin Kode ICD 10 didapatkan $4 \%$ atau sebanyak 2 responden. Pada poin perawatan didapatkan $96 \%$ atau sebanyak 43 responden dan paraf dokter gigi didapatkan $91 \%$ atau sebanyak 41 dokter gigi yang memberikan paraf pada rekam medis tersebut. Pada nomor 3 yaitu lampiran pelengkap didapatkan sebanyak $33 \%$ atau sebanyak 15 responden dokter gigi yang memiliki form inform consent, dan tidak ada yang menggunakan foto rontgen.

Gambar.2 Hasil Pengetahuan Hukum Dokter Gigi di Kota Semarang

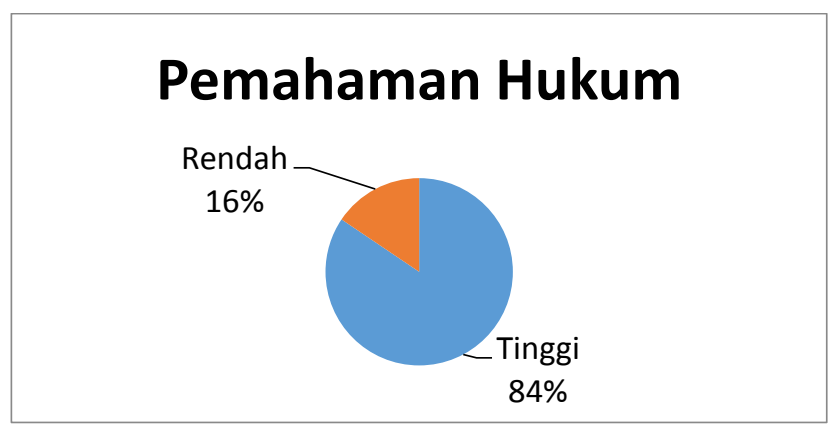

Berdasarkan gambar 2 didapatkan hasil bahwa sebesar $16 \%$ atau sebanyak 7 dokter gigi mendapatkan nilai rendah (di bawah nilai 50) dan sebesar $84 \%$ atau sebanyak 38 dokter gigi mendapatkan nilai tinggi (di atas nilai 50). 
Gambar.3 Hasil Sikap Dokter Gigi di Kota Semarang

\section{Sikap Dokter Gigi}

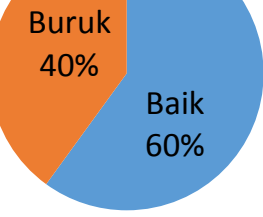

Berdasarkan gambar 3 didapatkan hasil bahwa 40\% responden atau sebanyak 18 dokter gigi memiliki sikap buruk dalam mengisi rekam medis dan $60 \%$ responden atau sebanyak 27 dokter gigi memiliki sikap yang baik dalam mengisi rekam medis.

Gambar 4 Hasil Prilaku Dokter Gigi di Kota Semarang

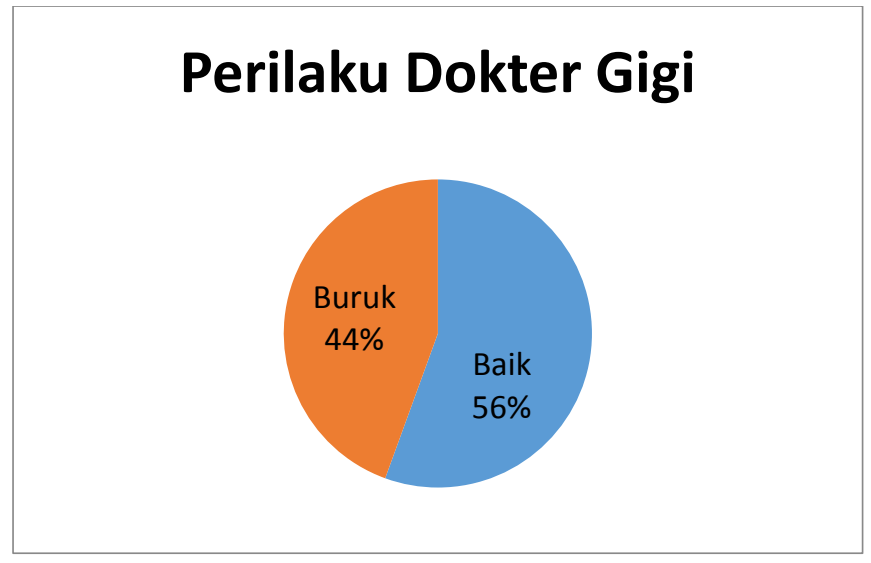

Berdasarkan gambar 4.4 didapatkan hasil bahwa 44\% responden atau sebanyak 20 dokter gigi memiliki perilaku buruk (dibawah rata-rata) dalam mengisi rekam medis dan $56 \%$ responden atau sebanyak 25 dokter gigi memiliki perilaku yang baik (diatas rata-rata) dalam mengisi rekam medis.

Tabel.2 Uji Regresi Logistik

Pengaruh pemahaman hukum,sikap, dan perilaku terhadap kelengkapan pengisian rekam medis

\begin{tabular}{|c|c|c|c|c|c|c|}
\hline \multicolumn{7}{|c|}{ Coefficients $^{a}$} \\
\hline & \multirow[b]{2}{*}{ Model } & \multicolumn{2}{|c|}{ Unstandardized Coefficients } & \multirow{2}{*}{$\begin{array}{c}\begin{array}{c}\text { Standardized } \\
\text { Coefficients }\end{array} \\
\text { Beta }\end{array}$} & \multirow{2}{*}{$\mathrm{t}$} & \multirow[b]{2}{*}{ Sig. } \\
\hline & & $\mathrm{B}$ & Std. Error & & & \\
\hline \multirow[t]{3}{*}{1} & (Constant) & .911 & .776 & & 1.174 & .247 \\
\hline & Pemahaman (X1) & .107 & .024 & .571 & 4.500 & .000 \\
\hline & Sikap (X2) & -.001 & .028 & -.003 & -.021 & .983 \\
\hline
\end{tabular}


Tabel 2 menunjukkan variabel pemahaman hukum koefisien regresinya sebesar 0,107 dengan tingkat signifikansi (p) sebesar 0,000 , lebih kecil dari 0,05. Pada tabel 3 didapatkan tingkat signifikan (p) sebesar 0,000. Kekuatan korelasi didapatkan sebesar 0,585 sehingga semakin besar nilai satu variabel, maka semakin besar pula nilai variabel lainnya. Dengan demikian pemahaman hukum berpengaruh terhadap kelengkapan pengisian rekam medis, variabel pemahaman hukum memiliki kekuatan sedang dengan arah korelasi searah (positif) atau $\mathrm{H} 1$ diterima dan $\mathrm{H} 0$ ditolak.

Tabel 2 juga menunjukkan menunjukkan variabel pemahaman hukum koefisien regresinya sebesar 0,001 dengan tingkat signifikansi $(p)$ sebesar 0,983, lebih besar dari 0,05. Tabel 3 didapatkan tingkat signifikan $(p)$ sebesar 0,785 . Kekuatan korelasi didapatkan sebesar 0,042 sehingga semakin besar nilai satu variabel, maka semakin besar pula nilai variabel lainnya. Dengan demikian sikap tidak berpengaruh terhadap kelengkapan pengisian rekam medis, variabel sikap memiliki kekuatan sangat lemah dengan arah korelasi searah (positif) atau $\mathrm{H} 1$ ditolak dan $\mathrm{H} 0$ diterima. Di tabel ini juga menunjukkan variabel pemahaman hukum koefisien regresinya sebesar -0,049 dengan tingkat signifikansi $(p)$ sebesar 0,316 lebih besar dari 0,05. Tabel 3 didapatkan tingkat signifikan ( $p$ ) sebesar 0,282 . Kekuatan korelasi didapatkan sebesar $-0,164$ sehingga semakin besar nilai satu variabel, maka semakin kecil pula nilai variabel lainnya Dengan demikian perilaku dokter gigi tidak berpengaruh terhadap kelengkapan pengisian rekam medis atau $\mathrm{H} 1$ ditolak dan $\mathrm{H} 0$ diterima.

Tabel.3 Uji Non-Parametrik Pengaruh masing-masing variabel

\section{Correlations}

\begin{tabular}{|c|c|c|c|c|c|c|}
\hline & & & $\begin{array}{c}\text { Pemahaman } \\
(\mathrm{X} 1)\end{array}$ & $\begin{array}{l}\text { Sikap } \\
(\mathrm{X} 2)\end{array}$ & $\begin{array}{c}\text { Perilaku } \\
\text { (X3) }\end{array}$ & $\begin{array}{l}\text { Kelengkapar } \\
\text { Rekam } \\
\text { Medis (Y) }\end{array}$ \\
\hline \multirow[t]{12}{*}{$\begin{array}{l}\text { Spearman's } \\
\text { rho }\end{array}$} & \multirow[t]{3}{*}{ Pemahaman (X1) } & $\begin{array}{l}\text { Correlation } \\
\text { Coefficient }\end{array}$ & 1.000 & .127 & -.105 & $.585^{* *}$ \\
\hline & & Sig. (2-tailed) & & .406 & .493 & .000 \\
\hline & & $\mathrm{N}$ & 45 & 45 & 45 & 45 \\
\hline & \multirow[t]{3}{*}{ Sikap (X2) } & $\begin{array}{l}\text { Correlation } \\
\text { Coefficient }\end{array}$ & .127 & 1.000 & -.042 & .042 \\
\hline & & Sig. (2-tailed) & .406 & & .786 & .785 \\
\hline & & $\mathrm{N}$ & 45 & 45 & 45 & 45 \\
\hline & \multirow[t]{3}{*}{ Perilaku (X3) } & $\begin{array}{l}\text { Correlation } \\
\text { Coefficient }\end{array}$ & -.105 & -.042 & 1.000 & -.164 \\
\hline & & Sig. (2-tailed) & .493 & .786 & & .282 \\
\hline & & $\mathrm{N}$ & 45 & 45 & 45 & 45 \\
\hline & \multirow[t]{3}{*}{$\begin{array}{c}\text { Kelengkapan } \\
\text { Rekam Medis }(\mathrm{Y})\end{array}$} & $\begin{array}{l}\text { Correlation } \\
\text { Coefficient }\end{array}$ & $.585^{* *}$ & .042 & -.164 & 1.000 \\
\hline & & Sig. (2-tailed) & .000 & .785 & .282 & \\
\hline & & $\mathrm{N}$ & 45 & 45 & 45 & 45 \\
\hline
\end{tabular}


${ }^{* *}$. Correlation is significant at the 0.01 level (2-tailed).

Tabel 3 pengaruh pemahaman hukum terhadap sikap dokter gigi menunjukkan tingkat signifikan ( $p$ ) sebesar 0,406. Kekuatan korelasi didapatkan sebesar 0,127 sehingga dikatakan kekuatan korelasi sangat lemah dengan arah korelasi searah, semakin besar nilai satu variabel, maka semakin besar pula nilai variabel lainnya.

Pengaruh pemahaman hukum terhadap perilaku dokter gigi memiliki tingkat signifikan (p) sebesar 0,493. Kekuatan korelasi didapatkan sebesar -

\section{DISKUSI}

Hasil penelitian ini didapatkan kelengkapan rekam medis dokter gigi yang masuk dalam kategori tidak lengkap sebesar $44 \%$ atau sebanyak 20 responden dokter gigi. Penulisan rekam medis yang termasuk kategori kurang lengkap sebesar $56 \%$ atau sebanyak 25 responden dokter gigi. Penelitian yang didapatkan tidak menemukan penulisan rekam medis dokter gigi yang termasuk ketegori lengkap. Akibat dari pengisian rekam medis yang tidak lengkap dapat mempengaruhi kualitas pelayanan. ${ }^{8}$ Membuat rekam medis dengan jelas dan lengkap bagi dokter/dokter gigi akan meningkatkan kualitas pelayanan untuk melindungi tenaga kesehatan medis dan mencapai kesehatan masyarakat yang optimal. ${ }^{9}$ Selain itu mengisi rekam medis secara jelas dan lengkap dapat melindungi tenaga kesehatan dalam masalah hukum, disiplin dan etik. Peran odontogram penting untuk pembuatan rencana perawatan secara menyeluruh dan dapat digunakan untuk data identifikasi. Hal ini disebabkan karena susunan gigi tidak beda jauh. dengan sidik jari setiap individu yang memiliki sidik jari berbeda sama halnya dengan susunan gigi sehingga pengisian rekam medis termasuk pengisian odontogram secara
0,105 sehingga dikatakan kekuatan korelasi sangat lemah dengan arah korelasi berlawanan arah, semakin besar nilai satu variabel, maka semakin kecil pula nilai variabel lainnya. Sedangkan pengaruh sikap dokter gigi terhadap perilaku dokter gigi memiliki tingkat signifikan (p) sebesar 0,786. Kekuatan korelasi didapatkan sebesar -0,045 sehingga dikatakan kekuatan korelasi sangat lemah dengan arah korelasi berlawanan arah, semakin besar nilai satu variabel, maka semakin kecil pula nilai variabel lainnya

lengkap dapat membantu pihak forensik dalam rangka pengidentifikasian korban bencana 10

Pengetahuan hukum terhadap rekam medis adalah segala sesuatu yang diketahui tentang proses pembentukan dan pemberlakuan hukum dalam pengisian rekam medis. Hasil penelitian ini didapatkan hasil bahwa $16 \%$ atau sebanyak 7 dokter gigi mendapatkan nilai rendah (di bawah nilai 50 ) dan $84 \%$ atau sebanyak 38 dokter gigi mendapatkan nilai tinggi (di atas nilai 50). Hal ini menunjukkan bahwa pengetahuan Dokter Gigi di Kota Semarang mengenai pengetahuan hukum rekam medis baik. Meskipun demikian, hendaknya semua dokter gigi memiliki pengetahuan yang baik tentang rekam medis terutama dokter gigi yang aktif berpraktik. Pengetahuan dokter gigi mengenai pemahaman hukum mempengaruhi dokter gigi dalam mengisi rekam medis, namun dokter gigi yang memiliki pengetahuan baik tentang rekam medis belum tentu mengisi rekam medis dengan baik dan benar tanpa didasari oleh kemauan dokter tersebut untuk mencari tahu tentang hukum rekam medis.

Hasil penelitian ini didapatkan hasil bahwa $40 \%$ responden atau sebanyak 18 dokter gigi memiliki sikap buruk dalam mengisi rekam medis 
dan $60 \%$ responden atau sebanyak 27 dokter gigi memiliki sikap yang baik dalam mengisi rekam medis. Hasil korelasi menunjukkan bahwa ada hubungan sikap terhadap kelengkapan rekam medis dokter gigi di Kota Semarang. Sikap yang baik dilatar belakangi oleh pengetahuan yang baik. Walaupun pengetahuan yang baik belum tentu memiliki sikap yang positif. Hal ini sesuai dengan penelitian terkait bahwa terdapat hubungan yang signifikan antara sikap dengan kelengkapan rekam medis. ${ }^{11.12}$

Hasil penelitian didapatkan hasil bahwa $44 \%$ responden atau sebanyak 20 dokter gigi memiliki perilaku buruk dalam mengisi rekam medis dan 56\% responden atau sebanyak 25 dokter gigi memiliki perilaku yang baik dalam mengisi rekam

\section{KESIMPULAN}

Berdasarkan penelitian yang sudah dijalankan, dapat ditarik suatu kesimpulan bahwa terdapat hubungan antara pengetahuan hukum dokter gigi terhadap kelengkapan pengisian rekam medis dan tidak terdapat hubungan antara sikap dan perilaku dokter gigi terhadap kelengkapan pengisian rekam medis..

\section{DAFTAR PUSTAKA}

1. Khasib M, E. R., Elsye M, R. And Suparniati (2013) 'Analisis Faktor-Faktor Yang Mempengaruhi Kepatuhan Pengisian Rekam Medis Di Rumah Sakit Gigi Dan Mulut Pendidikan Umy', Jmmr (Jurnal Medicoeticolegal Dan Manajemen Rumah Sakit), 2(2), Pp. 1-18.

2. Kencana, G., Rumengan, G. And Hutapea, F. (2019) 'Analisa Kepatuhan Pengisian Berkas Rekam Medis Di Instalasi Rawat Inap Rumah Sakit X', Jurnal Manajemen Kesehatan Yayasan Rs.Dr. Soetomo, 5(1), P. 27.

3. Ulfa, S. N. Dkk (2017) 'Faktor-Faktor Yang Mempengaruhi Kelengkapan Diagram Fishbone Di Rumah Sakit Pertamina Jaya', Jurnal Inohim, 5, Pp. 39-44. medis. Banyak faktor atau alasan yang menyebabkan seseorang untuk berperilaku, oleh sebab itu perilaku atau tindakan yang sama diantara beberapa orang dapat disebabkan atau dilatar belakangi oleh hal yang berbeda. Kelengkapan pengisian dokumen rekam medis dilatar belakangi hal-hal yang kompleks dari petugas kesehatan yang berkait dan berbeda antara satu dengan lainnya. ${ }^{11}$ Dalam teori perilaku bahwa seseorang yang memiliki pengetahuan baik belum tentu melakukan tindakan yang positif, karena perilaku atau tindakan seseorang dipengaruhi banyak hal yang kompleks. Perilaku akan bersifat lebih konsisten apabila didukung oleh pengetahuan yang baik. ${ }^{12,13.14}$

4. Wirajaya, M. K. And Nuraini, N. (2019) 'Faktor Faktor Yang Mempengaruhi Ketidaklengkapan Rekam Medis Pasien Pada Rumah Sakit Di Indonesia', Jurnal Manajemen Informasi Kesehatan Indonesia, 7(2), P. 165. Doi: 10.33560/Jmiki.V7i2.225.

5. Lihawa, C., \& Mansur, M. (2015). Faktor-Faktor Penyebab Ketidaklengkapan Pengisian Rekam Medis Dokter Di Ruang Rawat Inap Rsi Unisma Malang. Jurnal Kedokteran Brawijaya, 28(2), 119-123

6. Undang-Undang No. 29 tahun 2004 tentang Praktik Kedokteran

7. Permenkes No. 269/Menkes/Per/III/2008 Tentang RekaMedis

8. Winarti, S. S. (2013). Analisis Kelengkapan Pengisian Dan Pengembalian Rekam Medis Rawat Inap Rumah Sakit. Jurnal Administrasi Kesehatan Indonesia, 1(4), 345-351.

9. Soeparto, P. Et Al. (2006) Etik Dan Hukum Di Bidang Kesehatan. 2nd Edn. Surabaya: Airlangga University

10. Yusuf, M., Setiawan, S. And Kusuma, A. R. P. (2019) 'Gambaran Kelengkapan Dan Keseragaman Penulisan Odontogram Oleh Dokter Gigi Di Kota Semarang', Odonto : Dental Journal, 6, P. 40. Doi: 10.30659/Odj.6.0.40-44.

11. Basuki, R., Dewi, E. S. And Sundari, S. (2017) 'Hubungan Perilaku Petugas Kesehatan Terhadap Kelengkapan Isi Dokumen Rekam Medis Di Rumah Sakit Kota Malang (Studi Kasus Di Rsia Puri Malang)', Jurnal Dinamika Dotcom, 8(2), Pp. 1-15.

12. Sugiyanto, Z. (2006) 'Analisis Perilaku Dokter 
Dalam Mengisi Kelengkapan Data Rekam Medis Lembar Resume Rawat Inap Di Rs Ungaran Tahun 2005'.

13. Utami, S., Susilani, A. T., \& Hakam, F. (2016). Hubungan Tingkat Pengetahuan Tentang Rekam Medis Dengan Kelengkapan Pengisian Catatan Keperawatan Pada Instalasi Rawat Inap Di Rumah Sakit At-Turots Al Islamy Sleman. Jurnal Permata Indonesia. Volume 7

14. Kumalasari, R. R., Dharmawan, Y., \& Winarni, S. (2018). Hubungan Pengetahuan, Sikap Dan Usia Dokter Terhadap Kelengkapan Pengisian Berkas Rekam Medis Pada Pasien Bpjs Di Rumah Sakit Aisyiyah Bojonegoro. Jurnal Kesehatan Masyarakat (E-Journal), 6(4), 125131. 